\title{
G.I. Kovtun
}

\section{INTERFACIAL PROPERTIES OF CHITOSAN LACTATE AT THE LIQUID/AIR INTERFACE}

\author{
Institute of Applied Problems of Physics and Biophysics of National Academy of Sciences of Ukraine \\ 3 V. Stepanchenka Str., Kyiv,03142,Ukraine,E-mail: anna-kovtun@ukr.net
}

The interfacial properties (dynamic and equilibrium surface tension, viscosity and elasticity moduli) of chitosan lactate have been studied at the liquid/air interface by the oscillating drop shape method. Isotherms of dynamic surface tension of chitosan lactate are similar to dependences for other polyelectrolyte solutions, in particular for proteins. Chitosan is a weak cationic polyelectrolyte which can change its conformation from a linear rod to a chaotic and compacted coil. Therefore, the experimental dependence of the equilibrium surface tension on concentration of chitosan lactate was analyzed with the adsorption model proposed earlier for proteins. This model accounts the possibility of polyelectrolyte molecules existence in surface layer in $n$ states with different molar surface varying from the maximum value at very low surface coverage by polyelectrolyte molecules to a minimum value at high surface coverage. Good agreement between the calculated and experimental values of surface tension was observed. The dependences of the elasticity and viscosity moduli of chitosan lactate solutions on the drop oscillations frequency are conditioned by the influence of exchange processes both between the surface layer and the bulk solution and in the surface layer itself. An increase of the solution concentration intensifies the exchange processes, and an increase of the oscillation frequency suppresses them. It is shown that the dependence of the surface viscoelasticity modulus of chitosan lactate is extreme in nature with a pronounced maximum. The reason for such behavior is the possibility of changing the molar surface area of the polyelectrolyte at the interface dependent on the amount of adsorption and its structural properties. Attempt of theoretical description of the viscoelasticity modulus within the framework of model accounting mono- or bilayer adsorption did not lead to a satisfactory result, possibly due to barrier adsorption mechanism of chitosan. But bilayer model provide qualitative description of extreme behavior of surface viscoelasticity on concentration. The values of the surface viscoelasticity modulus of chitosan lactate occupy an intermediate position in comparison with the data available in the literature for globular and flexible-chain proteins, that is consistent with their molecular structure. In addition, the work shows the applicability of the adsorption model, developed earlier for proteins in the framework of a nonideal two-dimensional solution theory, for describing the surface properties of other polyelectrolytes. This makes it possible to obtain qualitative and quantitative information about the processes occurring in the systems under study.

Keywords: chitosan, surface tension, viscoelasticity modulus, adsorption model, liquid/air interface

\section{INRODUCTION}

Biocompatibility, biodegradability and the presence of active functional groups in natural polysaccharide chitosan promote its application in the food industry, cosmetology, biomedical and synthetic purposes, for example, in microencapsulation of substances to prolong their action [1,2], in the production of foams [3], emulsions [4, 5], films [6], fibers [7], and also as rheological modifiers. It is well known that the adsorption and rheological properties of surfactants at the interfaces play an important role in the creation of stable layers on the surface of nano-, microparticles, capsules, emulsion drops; mechanical properties of polymer composite materials. Surface rheology methods in comparison to tensiometry methods are more informative in application to adsorption layers of polymers, for which conformational transitions can occur at a constant surface pressure [8]. Chitosan is characterized by low surface activity $[3,5,9,10]$. Complexation of chitosan with anionic surfactants, as well as alkylation of chitosan, leads to increasing of its surface activity $[3,4,9,11-13]$. The interfacial behavior of alkylated chitosans is similar to that for proteins, the desorption rate of which is very low, and the desorption mechanism is barrier $[9,13]$. The surface rheological properties of the chitosan are less studied. According to $[9,14,15]$, the adsorption layers of chitosan are viscoelastic with comparable real and imaginary parts of the viscoelasticity modulus. The dependence of the surface elasticity on concentration of chitosan solutions was not measured. An increase in the electrolyte concentration in solutions of chitosan and alkylated chitosan leads to an increase in the 
elastic modulus of the adsorption layers [15]. The aim of this work was to investigate the dynamic and equilibrium surface tension, elasticity and viscosity moduli of the surface layers of chitosan lactate at the liquid/air interface and to find a possibility of using theoretical adsorption model developed for proteins. This will contribute to the development of understanding the properties and features of the chitosan surface layers formation.

\section{EXPERIMENTAL}

Chitosan with a molecular weight of $75 \mathrm{kDa}$ and a degree of deacetylation of $70 \%$ was used in this work. Chitosan was dissolved in an aqueous solution of $2 \%$ lactic acid. The $\mathrm{pH}$ of the resulting chitosan lactate solution was 4.0.

The interfacial properties (dynamic and equilibrium surface tension, viscoelasticity modulus) of chitosan lactate were studied at the liquid/air interface by the oscillating drop shape method (PAT-2P, SINTERFACE Technologies, Germany) at $25 \pm 0.1{ }^{\circ} \mathrm{C}$ [16]. A drop of the studied chitosan lactate solution was formed at the tip of a vertical capillary. At first, the surface area of a freshly formed drop was kept constant at $A_{0}$ until adsorption equilibrium was reached. Equilibrium surface tension was achieved at a surface lifetime of 20000 s. Then the drop surface area was changed in a sinusoidal way with frequencies $v$ in the range from 0.005 to 0.2 $\mathrm{Hz}$ and surface area deformation amplitudes $\triangle A / A_{0}$ of $5-7 \%$. The results of experiments with harmonic oscillations can be analyzed by using a Fourier transformation [17]:

$E(i 2 \pi v)=A_{0} \frac{F[\Delta \gamma]}{F[\Delta A]}$.

The dilational modulus $E$ is a complex number that includes real and imaginary components: $E(i 2 \pi v)=E_{r}+i E_{i}$. The real part $E_{\mathrm{r}}$ (elasticity modulus) reflects the accumulation of energy, and the imaginary part $E_{\mathrm{i}}$ (viscosity modulus) is the energy loss in the surface layer due to relaxation processes. The viscoelasticity modulus $|E|$ is determined as:

$|\mathrm{E}|=\sqrt{\mathrm{E}_{i}^{2}+\mathrm{E}_{r}^{2}}$.

\section{RESULTS AND DISCUSSION}

Isotherms of dynamic surface tension for various concentrations of chitosan lactate are presented in Fig. 1. The nature of these dependences at low concentrations in the bulk of solution is similar to those for protein solutions [18], and also agrees with the results obtained in $[9,12,19]$ for chitosan and its alkylated derivatives, for which the stages of "induction", "post-induction" and the final stage on isotherms of dynamic surface tension were observed. For low concentrations of chitosan lactate (Fig. 1, curves 1-3), at first, a very slow decrease in surface tension is characteristic. The number of molecules in the surface layer is small, the electrostatic repulsion between charged amino groups in the aqueous phase at this stage of adsorption is negligible. At the next stage of adsorption, a strong decrease in surface tension occurs, while the rate of decrease in surface tension is maximum. These stages are often observed in the case of hydrophilic polymers and proteins, the adsorption of which is determined by the diffusion of macromolecules from the bulk of the solution to the interface $[9,18]$. The first two stages are characterized by relatively loose packing of macromolecules in the surface layer and low intermolecular interactions. In this case, the adsorption rate is mainly determined by the diffusion of macroions from the solution to the surface. At the end of the second stage and at the last stage of adsorption, the already formed adsorption layer begins to act as a repulsive barrier in relation to macroions reaching the surface. This manifests itself in a significant decrease in the rate of decrease in surface tension. The decrease in the surface tension over long periods of time indicates that the already adsorbed macromolecules control the diffusion of active segments by their own redistribution in the adsorption layer. With an increase in the concentration of chitosan lactate (Fig. 1, curve 4), the first stage, characterized by a slow decrease of surface tension with time, disappears and only two subsequent stages are observed with a strong decrease in surface tension, which is replaced by a decrease in speed $d \gamma / d t$.

Chitosan is a weak cationic polyelectrolyte. Due to capability of its macromolecules to exist in different conformational states $[20,21]$ from a linear rod to a chaotic and compacted coil dependent on the $\mathrm{pH}$, ionic strength, temperature, concentration, etc., the nonideal two-dimensional solution model proposed for proteins in $[18,22]$, was applied to description of the equilibrium surface pressure of chitosan lactate. According to 
model [18, 22], polyelectrolyte molecules can exist in surface layer in $n$ states with different molar surface varying from the maximum value, $\omega_{n}$, at very low surface coverage by polyelectrolyte molecules to a minimum value, $\omega_{1}$, at high surface coverage. The molar surface of the polyelectrolyte in the $i$ state is equal to $\omega_{i}=\omega_{1}+(i-1) \omega_{0}$, $(1 \leq i \leq \mathrm{n})$, where $\omega_{0}$ is the increment of the molar surface during the transition from one state to another. The equation of state for the surface layer of polyelectrolyte is:

$-\frac{\Pi \omega_{0}}{R T}=\ln (1-\theta)+\theta\left(1-\omega_{0} / \omega\right)+a \theta^{2}$,

where $\Pi=\left(\gamma_{0}-\gamma\right)-$ surface pressure; $\gamma$ and $\gamma_{0}$ are the surface tension of the solution and pure solvent; $R$ is the universal gas constant; $T$ is the temperature; $a$ is the parameter that accounts intermolecular interaction between adsorbed molecules, $\theta=\omega \Gamma=\sum_{i=1}^{n} \omega_{i} \Gamma_{i}$ is the total surface coverage by polyelectrolyte molecules with an average molar surface $\omega$.

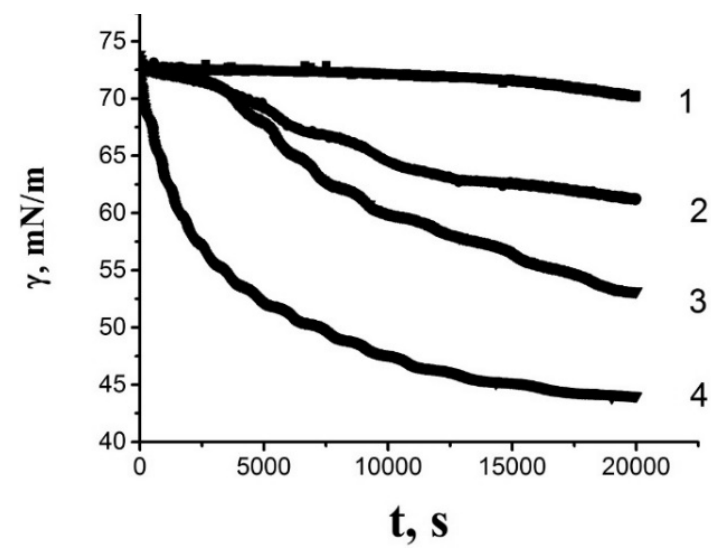

Fig. 1. Dependences of dynamic surface tension on time for chitosan lactate solutions with concentration: $1-0.2 ; 2-0.3 ; 3-0.4 ; 4-0.7 \mathrm{~g} / 1$

The adsorption isotherm for $j$ state of the polyelectrolyte molecule in the surface layer is:

$b c=\frac{\omega \Gamma_{j}}{(1-\theta)^{\omega_{j} / \omega}} \exp \left[-2 a \frac{\omega_{j}}{\omega} \theta\right]$,

where $c$ is the concentration of the polyelectrolyte in the solution bulk, $b=b_{j}$ is the adsorption equilibrium constant, $\Gamma_{j}$ is the distribution function of adsorptions of polyelectrolyte in different states determined by the ratio:

$$
\Gamma_{j}=\Gamma \frac{(1-\theta)^{\left(\omega_{j}-\omega_{1}\right) / \omega} \exp \left[2 a \theta \frac{\omega_{j}-\omega_{1}}{\omega}\right]}{\sum_{i=1}^{n}(1-\theta)^{\left(\omega_{i}-\omega_{1}\right) / \omega} \exp \left[2 a \theta \frac{\omega_{i}-\omega_{1}}{\omega}\right]} .
$$

$\Gamma$ is the total adsorption of the polyelectrolyte in all $n$ states. Equal adsorption probability for all polyelectrolyte states, with equal values of the $b_{j}$ constants for all states $j$ from $i=1$ to $i=n$ is assumed. The adsorption constant for the protein molecule as a whole is $\sum b_{j}=n b_{j}$.

At high concentrations, solutions of proteins are capable of forming bilayers (or polylayers) at liquid interfaces [22]. The degree of coverage of the second layer is proportional to the adsorption equilibrium constant $b_{I I}$ and the coverage degree of the first layer (it is assumed that the formation of the second and subsequent layers does not affect the surface pressure). The bilayer adsorption isotherm is given by [23]:

$$
\Gamma_{\Sigma}=\Gamma\left[1+\frac{b_{I I} c}{1+b_{I I} c}\right]
$$

where $\Gamma_{\Sigma}$ is the total adsorption in the first and second layers.

For description of the chitosan lactate adsorption behavior by the model $[18,22]$ maximum and minimum surface areas were determined from the results of measurements of the thickness of the adsorption layer $\delta \cong \mathrm{V} / \omega_{\max (\min )}$ according to procedure described in [22], where $V$ is the molar volume of the polyelectrolyte. The thickness of the adsorption layer for various chitosan samples at different $\mathrm{pH}$ values vary within 2-15 $\mathrm{nm}[4,23]$. Assuming that the molar volume of chitosan is $V \cong 75000 \mathrm{~cm}^{3} / \mathrm{mol}$, then the molar area of chitosan can vary from approximately $5.0 \times 10^{6}$ to $3.75 \times 10^{7} \mathrm{~m}^{2} / \mathrm{mol}$. The parameters $\omega_{n}$ and $\omega_{1}$ were chosen close to these values. The parameters $\omega_{0}, a$, and $b$ were found by fitting the experimental dependence of surface pressure on concentration.

The experimental and calculated dependence of the equilibrium surface pressure on the chitosan lactate concentration at $\mathrm{pH} 4.0$ at the liquid/air interface are shown in Fig. 2. The surface pressure increases with an increase of chitosan concentration to $1.0 \mathrm{~g} / \mathrm{l}$, after which it remains almost constant. This could be caused by the possible formation of aggregates in solution bulk 
and changes in the surface layer structure or multilayer formation, the last is typical for protein solutions $[18,22,24]$. The parameter values for the calculated according to Eqs. (3) and (4) for the concentration range before the plateau are the following: $\omega_{n}=1.1 \cdot 10^{7} \mathrm{~m}^{2} / \mathrm{mol}, \omega_{1}=6.9 \cdot 10^{6} \mathrm{~m}^{2} / \mathrm{mol}$, $\omega_{0}=1.1 \cdot 10^{5} \mathrm{~m}^{2} / \mathrm{mol}, \quad a=0.9, b=10 \mathrm{~m}^{3} / \mathrm{mol}$ (for the whole molecule $\Sigma b=n b=380 \mathrm{~m}^{3} / \mathrm{mol}$ ). Good agreement between the experimental and calculated dependences of surface pressure on concentration in the concentration range before reaching a plateau is shown.

The calculated dependences of the adsorption $\Gamma$ (curve 1) on the concentration of chitosan lactate for monolayer and for the bilayer adsorption model (curve $1^{*}, b_{I I}=8 \mathrm{~m}^{3} / \mathrm{mol}$ ) are presented in Fig. 3. The values of $\Gamma_{\Sigma}$ obtained for the case of bilayer adsorption in the concentration range of more than $0.2 \mathrm{~g} / \mathrm{l}$ are higher no more than $7 \%$ in comparison to values obtained for monolayer adsorption of $\Gamma$. However, as will be shown below, the use of the bilayer model is in better agreement with dilational rheological experiments.

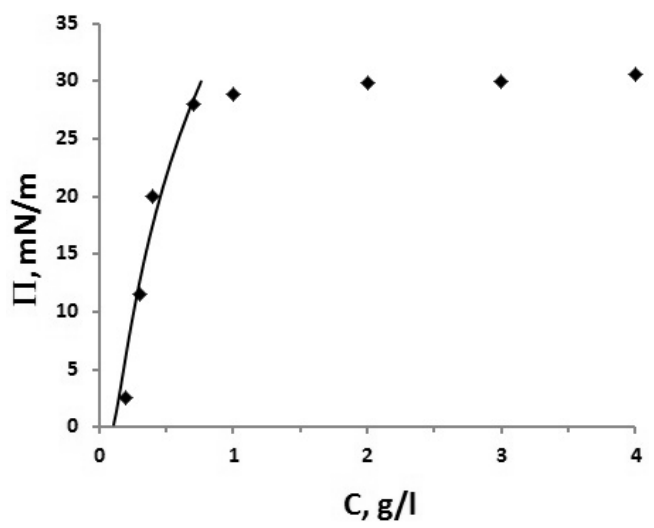

Fig. 2. Dependence of the equilibrium surface pressure on the chitosan lactate concentration: points experimental data, curve - calculated data for the concentration range before the plateau according to Eqs. (3-4) with the parameters described in the text

The dependences of the elasticity and viscosity moduli of chitosan lactate solutions on the drop oscillations frequency are shown in Fig. 4. The moduli for low concentrations of chitosan lactate are almost independent on frequency. As the concentration of chitosan lactate increases an increase in the elasticity modulus is observed with an increase in the oscillation frequency. The value of viscosity modulus decreases with an increase of the oscillations frequency for solutions with an increase in the oscillation frequency. These regularities are conditioned by the influence of exchange processes both between the surface layer and the bulk solution and in the surface layer itself. An increase of the solution concentration intensifies the exchange processes, and an increase of the oscillation frequency suppresses them.

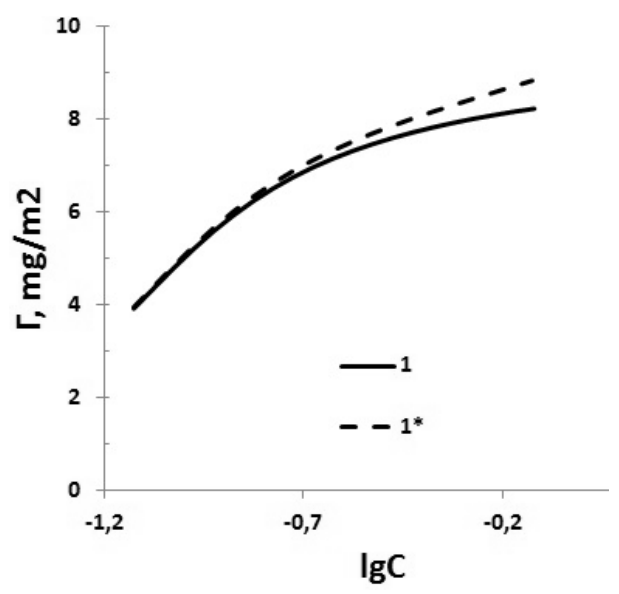

Fig. 3. Calculated dependences of the adsorption value $\Gamma(1)$ for monolayer adsorption on the concentration of chitosan lactate, and $\Gamma_{\Sigma}\left(1^{*}\right)$ - for bilayer adsorption

Fig. 5 shows the dependences of the viscoelasticity modulus of chitosan lactate solutions on concentration at two frequencies: 0.01 and $0.1 \mathrm{~Hz}$. There is a maximum at a concentration $C \approx 0.5-0.7 \mathrm{~g} / 1$ on dependences of the viscoelasticity modulus on concentration. Such behavior could be conditioned by the decrease of the molar surface of the polyelectrolyte at the surface layer with adsorption increase as follows from Eqs. (3-6) [18]. As example, flexible chain proteins are capable to unfold at the surface layer at low values of adsorption and surface pressure. So, the molar surface of a protein can change significantly with a change of surface pressure $[18,22]$.

Chitosan is characterized by barrier mechanism of adsorption. So for precise theoretical analysis of viscoelasticity modulus it is necessary to use a general theory [26], which takes into account the barrier adsorption mechanism.

For a qualitative description of the viscoelasticity modulus and understanding of the processes occurring in the surface layer we made an attempt to compare the values of the viscoelasticity modulus at $0.1 \mathrm{~Hz}$ with the value of 
the limiting (high-frequency) elasticity modulus $E_{0}=-d \gamma / d \ln \Gamma_{\Sigma}$ due to low phase angle values at this frequency (less than $10-15^{\circ}$ ). A similar technique was used in Refs. $[18,25]$ for proteins. The calculated dependence of the limiting elasticity modulus $E_{0}$ predicts an infinite increase of the viscoelasticity modulus for the case of monolayer adsorption. The bilayer adsorption model better describes the experimental data (in contrast to the monolayer). Calculated dependence shows the extreme behavior of the $|E|=\mathrm{f}(c)$ dependence (Fig. 5, solid line); however, it was not possible to achieve complete agreement between the experimental and calculated values which confirm the need to use a theory that takes into consideration the barrier adsorption mechanism.

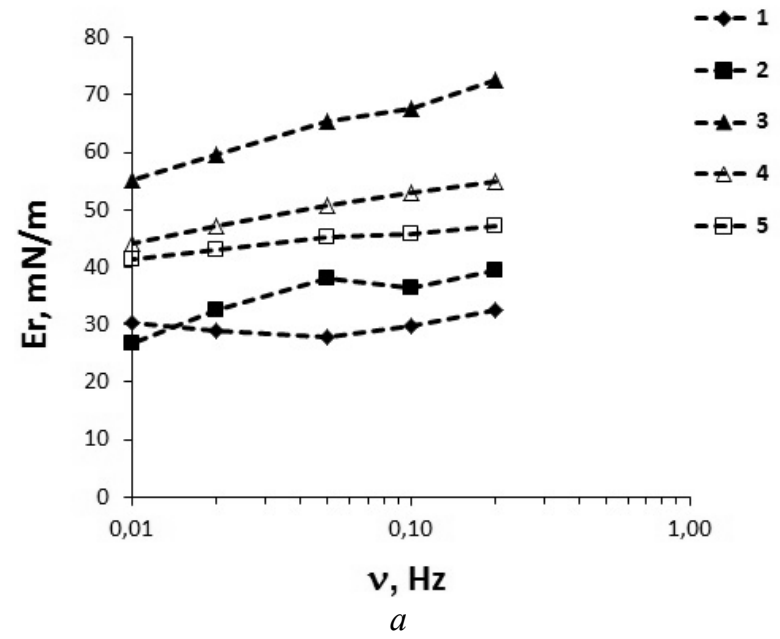

Comparison of the experimental values of the viscoelasticity modulus for chitosan lactate with data for $\beta$-casein and $\beta$-lactoglobulin at a surface oscillation frequency of $0.1 \mathrm{~Hz}$ obtained in Ref. [27] by the oscillating drop shape method have shown that the absolute values of the viscoelasticity for chitosan lactate occupy an intermediate position in comparison with globular $\beta$-lactoglobulin and flexible-chain $\beta$-casein. The maximum viscoelasticity modulus values for the chitosan lactate correspond to the region of higher surface pressure values, as for flexible-chain $\beta$-casein. The chitosan studied in this work has a relatively low degree of deacetylation, which probably contributes to a decrease in the charge density and allows it to change its molar surface, forming more compact structures, and may cause the formation of elastic adsorption layers.

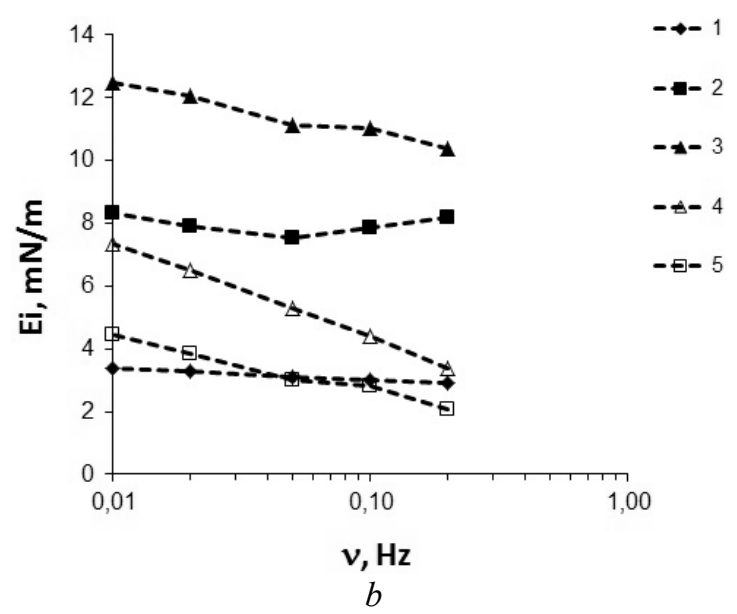

Fig. 4. Dependences of the surface elasticity $(a)$ and viscosity modulus $(b)$ on the frequency of drop oscillations at various concentrations of chitosan lactate solution, $\mathrm{g} / 1$ : $1-0.2 ; 2-0.4 ; 3-0.55 ; 4-0.7 ; 5-1.0$. Points represent experimental data, lines are guides for the eye

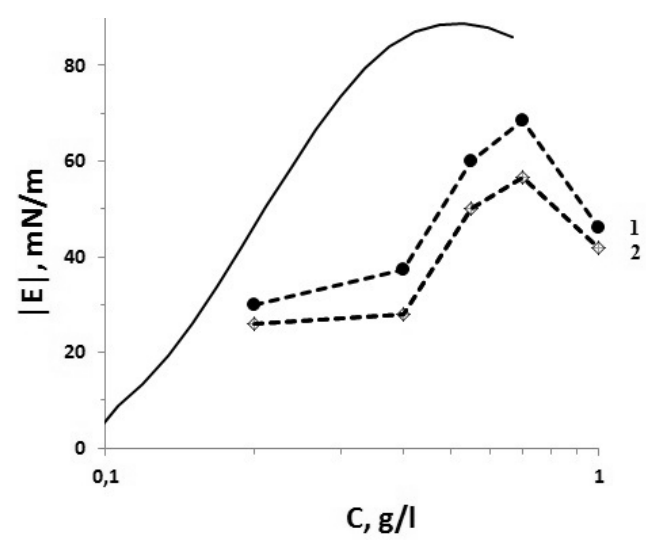

Fig. 5. Dependences of the surface viscoelasticity modulus $(1,3)$ on the concentration of chitosan lactate solution at an oscillation frequency: $1-0.1 \mathrm{~Hz} ; 3-0.01 \mathrm{~Hz}$. Solid line is the elasticity calculated by Eqs. (3-6) for the case of bilayer adsorption 


\section{CONCLUSIONS}

The dynamic and equilibrium surface tension, viscosity and elasticity moduli of chitosan lactate were studied at the liquid/air interface by the oscillating drop shape method. Isotherms of dynamic surface tension of chitosan lactate are similar to dependences for other polyelectrolyte solutions, in particular for proteins. The experimental dependence of the equilibrium surface tension on concentration of chitosan lactate is in good agreement with calculated on the base of adsorption model proposed earlier for proteins.

The dependences of the elasticity and viscosity moduli of chitosan lactate solutions on the drop oscillations frequency are conditioned by the influence of exchange processes both between the surface layer and the bulk solution and in the surface layer itself. An increase of the solution concentration intensifies the exchange processes, and an increase of the oscillation frequency suppresses them. It is shown that the dependence of the surface viscoelasticity modulus of chitosan lactate is extreme in nature with a pronounced maximum. The reason for such behavior is the possibility of changing the molar surface area of the polyelectrolyte at the interface dependent on the amount of adsorption and its structural properties. Attempt of theoretical description of the viscoelasticity modulus within the framework of model accounting mono- or bilayer adsorption did not lead to a satisfactory result possibly due to barrier adsorption mechanism of chitosan. But bilayer model provides qualitative description of extreme behavior of surface viscoelasticity on concentration and evidences the possibility of multilayer adsorption for chitosan. Obtained results indicate the need to use a theory that takes into consideration the barrier adsorption mechanism for precise description of surface rheological behavior. The values of the surface viscoelasticity modulus of chitosan lactate occupy an intermediate position in comparison with the data available in the literature for globular and flexible-chain proteins that is consistent with their molecular structure.

The work shows the applicability of the adsorption model, developed earlier for proteins in the framework of a nonideal two-dimensional solution theory, for describing the equilibrium surface tension of other polyelectrolytes. However it gives only quantitative description of viscoelasticity modulus for polyelectrolytes with barrier adsorption mechanism. This makes it possible to obtain qualitative and quantitative information about the processes occurring in the systems under study.

\section{ACKNOWLEDGEMENTS}

The author acknowledge the assistance in theoretical processing of experimental data by Dr. Prof. V.B. Fainerman.

\title{
Міжфазні властивості лактату хітозану на межі розділу рідина/повітря
}

\author{
Г.І. Ковтун
}

\author{
Інститут прикладних проблем фізики і біофізики Національної академії наук Украӥни \\ вул. В. Степанченка, 3, Київ, 03142, Україна, anna-kovtun@ukr.net
}

\begin{abstract}
Міжфазні властивості (динамічний та рівноважний поверхневий натяг, модулі в'язкості та пружності) лактату хітозану досліджувались на межі поділу рідина/повітря методом форми осцилюючої краплі. Ізотерми динамічного поверхневого натягу лактату хітозану подібні до залежностей для інших розчинів поліелектролітів, зокрема для білків. Хітозан - слабкий катіонний поліелектроліт, який може змінювати свою конформацію від лінійного стрижня до хаотичного $і$ ущільненого клубка. Тому експериментальну залежність рівноважного поверхневого натягу від концентрації лактату хітозану аналізували за допомогою моделі адсорбиії, запропонованої раніше для білків. Ця модель враховує можливість існування молекул поліелектроліту в поверхневому шарі в $n$ станах з різною молярною поверхнею, щз варіюється від максимального значення при дуже низькому заповненні поверхні молекулами поліелектроліту до мінімального значення при високому заповненні поверхні. Досягнуто хорошої згоди між розрахунковими та експериментальними значеннями поверхневого натягу. Залежності модулів пружності
\end{abstract}


та в'язкості розчинів лактату хітозану від частоти коливань краплі обумовлені впливом обмінних процесів як між поверхневим шаром та об'ємом розчину, так і в самому поверхневому шарі. Збільшення концентраціі розчину посилює обмінні процеси, а збільшення частоти коливань пригнічує їх. Показано, щзо залежність модуля поверхневої в'язкопружності лактату хітозану має екстремальний характер $з$ вираженим максимумом. Причиною такої поведінки є можливість зміни площі молярної поверхні поліелектроліту на межі розділу в залежності від величини адсорбиії та його структурних властивостей. Спроба теоретичного опису модуля в'язкопружності в рамках моделі, щзо враховує моно- або двошарову адсорбиію, не привела до задовільного результату, можливо, через бар'єрний механізм адсорбиії хітозану. Але двошарова модель дає якісний опис екстремальної поведінки поверхневої в'язкопружності від концентрації. Значення модуля поверхневої в'язкопружності лактату хітозану займають проміжне місце порівняно $з$ наявними в літературі даними для глобулярних білків та білків з гнучкими ланцюгами, що узгоджується 3 їхньюю молекулярною структурою. Крім того, робота показує придатність моделі адсорбиії, розробленої раніме для білків в рамках теорії неідеального двовимірного розчину, для опису поверхневих властивостей інших поліелектролітів. Це дає можливість отримати якісну та кількісну інформацію про процеси, щчо відбуваються в досліджуваних системах.

Ключові слова: хітозан, поверхневий натяг, модуль в'язкопружності, адсорбиійна модель, межа розділу рідина/повітря

\section{REFERENCES}

1. Negi P., Sharma G., Verma C., Garg P., Rathore Ch., Kulshrestha S., Lal U.R., Gupta B., Pathania D. Novel thymoquinone loaded chitosan-lecithin micelles for effective wound healing: Development, characterization, and preclinical evaluation. Carbohydr. Polym. 2020. 230: 115659.

2. Ullah F., Javed F., Kudus M.H.A., Khan A.N., Akil H.Md. Determining the molecular-weight and interfacial properties of chitosan built nanohydrogel for controlled drug delivery applications. Biointerface Res. Appl. Chem. 2019. 9(6): 4452.

3. Zinoviadou K.G., Scholten E., Moschakis T., Biliaderis C.G. Engineering interfacial properties by anionic surfactant-chitosan complexes to improve stability of oil-in-water emulsions. Food Funct. 2012. 3(3): 312.

4. Santini E., Jarek E., Ravera F., Liggieri L., Warszynski P., Krzan M. Surface properties and foamability of saponin and saponin-chitosan systems. Colloids Surf., B. 2019. 181: 198.

5. Wang X.-Y., Wang J., Rousseau D., Tan Ch.-H. Chitosan-stabilized emulsion gels via pH-induced droplet flocculation. Food Hydrocolloids. 2020. 105: 105811.

6. Liu M.M., Zhou Y., Zhang Y., Yu Ch., Cao Sh. Preparation and structural analysis of chitosan films with and without sorbitol. Food Hydrocolloids. 2013. 33(2): 186.

7. Poshina D.N., Kryzhanovskaya V.S., Torkunova E.A., Sukhova A.A., Skorik Y.A. Influence of the composition of water chitosan lactate solutions on their properties and electrospinning. Izvestia Ufimskogo Nauchnogo Tsentra RAN. 2018. 3(3): 90. [in Russian].

8. Monroy F., Ortega F., Rubio R.G., Noskov B.A. Surface rheology studies of spread and adsorbed polymer layers. In: Progress in Colloid and Interface Science, Interfacial Rheology. V. 1. (Leiden: Brill, 2009). P. 178.

9. Debrier J., Babak V.G. Interfacial properties of amphiphilic systems on the basis of natural polymers-chitin derivatives. Russ. J. Gen. Chem. 2008. 78(11): 2230.

10. Fricke N., Keul H., Moller M. Synthesis of Chitosan Surfactants. Macromol. Chem. Phys. 2009. $21(9): 752$.

11. Vikhoreva G.A., Chernukhina A.I., Strokova N.G., Gal'braikh L.S. Preparation and investigation of solutions of chitosan derivatives with long-chain hydrophilic substituents. Polym. Sci. Ser. B. 2007. 49(5-6): 131.

12. Babak V.G., Desbrieres J. Dynamic surface tension of hydrophobically modified chitosans. Mendeleev Commun. 2004. 14(2): 66.

13. Pérez-Gramatges A., Matheus C.R.V., Lopes G., da Silva J.C. Surface and interfacial tension study of interactions between water-soluble cationic and hydrophobically modified chitosans and nonylphenolethoxylate. Colloids and Surfaces A: Physicochem. Eng. Aspects. 2013. 418: 124.

14. Babak V.G., Baros F., Boury F., Desbrieres J. Dilational viscoelasticity and relaxation properties of interfacial electrostatic complexes between oppositely charged hydrophobic and hydrophilic polyelectrolytes. Colloids Surf. B. 2008. 65: 43 . 
15. Babak V.G., Auzely R., Rinaudo M. Effect of electrolyte concentration on the dynamic surface tension and dilational viscoelasticity of adsorption layers of chitosan and dodecyl chitosan. J. Phys. Chem. B. 2007. 111(32): 9519.

16. Zholob S.A., Kovalchuk V.I., Makievski A.V., Krägel J. Determination of the dilational elasticity and viscosity from the surface tension response to harmonic area perturbations. In: Progress in Colloid and Interface Science, Interfacial Rheology. V. 1. (Leiden: Brill, 2009). P. 77.

17. Zholob S.A., Makievski A.V., Miller R., Fainerman V.B. Optimization of calculation methods for determination of surface tensions by drop profile analysis tensiometry. Adv. Colloid Interface Sci. 2007. 134135: 322.

18. Fainerman V.B., Miller R. Equilibrium and Dynamic Characteristics of Protein Adsorption Layers at GasLiquid Interfaces: Theoretical and Experimental Data. Colloid J. 2005. 67: 393.

19. Babak V.G., Desbrieres J. Dynamic surface tension and dilational viscoelasticity of adsorption layers of alkylated chitosans and surfactant-chitosan complexes. Colloid Polym. Sci. 2006. 284: 745.

20. Davydova V.N., Yermak I.M. The Conformation of Chitosan Molecules in Aqueous Solutions. Biophysics. 2008. 63: 501.

21. Cunha R.A., Soares Th.A., Rusu V.H., Pontes F.J.S., Franca E.F., Lins R.D. The molecular structure and conformational dynamics of chitosan polymers: an integrated perspective from experiments and computational simulations. In: The Complex World of Polysaccharides. Ch. 9. (Intech Open, 2012). P. 229.

22. Fainerman V.B., Lucassen-Reynders E.H., Miller R. Description of the adsorption behaviour of proteins at water/fluid interfaces in the framework of a two-dimensional solution model. Adv. Colloid Interface Sci. 2003. 106: 237.

23. Tiraferri A., Maroni P., Caro Rodríguez D., Borkovec M. Mechanism of chitosan adsorption on silica from aqueous Solutions. Langmuir. 2014. 30: 4980.

24. Fainerman V.B., Aksenenko E.V., Makievski A.V. Trukhin D.V., Yeganehzad S., Gochev G., Miller R. Surface tension and dilational rheology of mixed $\beta$-casein - $\beta$-lactoglobulin aqueous solutions at the water/air interface. Food Hydrocolloids. 2020. 106: 1.

25. Lucassen-Reynders E.H., Fainerman V.B., Miller R. Surface dilational modulus or Gibbs elasticity of protein adsorption layers. J. Phys. Chem. B. 2004. 108: 9173.

26. Noskov B.A., Latnikova A.V., Lin S.-Y., Loglio G., Miller R. Dynamic surface elasticity of $\beta$-casein solutions during adsorption. J. Phys. Chem. C. 2007. 111(45): 16895.

27. Benjamins J., Lyklema J., Lucassen-Reynders E.H. Compression/expansion rheology of oil/water interfaces with adsorbed proteins. Comparison with the air/water surface. Langmuir. 2006. 22: 6181. 